\title{
In Memoriam \\ Professor Ryszard Ligowski \\ (1946-2017) \\ a scientist and a polar explorer
}

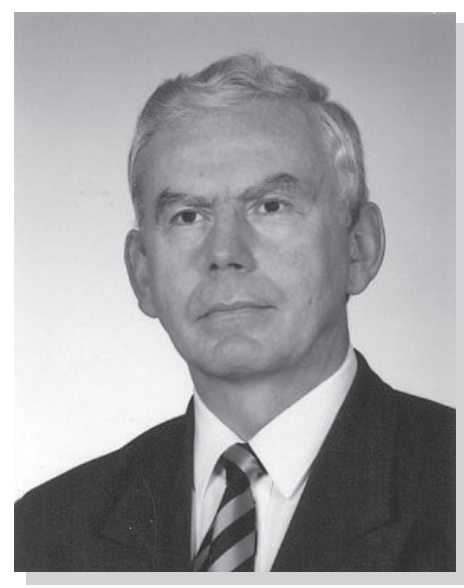

On the 3rd of February 2017, we lost Professor Ryszard Ligowski, an experienced naturalist, biologist and botanist, a prominent specialist in biology and ecology of marine and freshwater algae as well as a world-renown diatomologist.

Professor Ligowski, born in 1946, earned his M.Sc. in 1969 having graduated from the Faculty of Biology and Earth Sciences, University of Łódź. He received his Ph.D. in 1978. His D.Sc. degree was conferred on him in recognition of his dissertation on Marine diatoms (Bacillariophyceae) in Antarctic ecosystem and their importance as an indicator of food source of krill (Euphausia superba Dana) in 1994. In 2002, he received full professorship. Professor Ligowski's scientific achievements are recorded in numerous original publications, including papers synthesising different aspects of knowledge on biodiversity of Antarctic diatoms, their role in the trophic web of the marine Antarctic ecosystem, structure and dynamics of sympagic diatoms in the Antarctic as well as ecology and taxonomy of freshwater diatoms. A substantial part of Professor Ligowski was a widely recognized and respected representative of the world's community of phycologists. Since 1998, he had been a member of the International Society of Diatom Research; he also belonged to numerous other associations, societies, committees and scientific councils.

At the beginning of his career as a researcher, in the 1970s, he focused, as a scientist working at the Department of Algology, Faculty of Biology and Earth Sciences, University of Łódź, on biology and ecology of freshwater algae, primarily diatoms. 
At the beginning of the 1980s, he vigorously entered the sphere of emerging Polish research in the Antarctic. At that time, he joined the team of polar biologists in the Chair of Invertebrate Zoology and Hydrobiology, University of Łódź. Professor Ligowski's exploration of the seas of the Far South resulted in a long sequence of scientific achievements, brought to a halt by his sudden, unexpected death.

He took part in four (the 7th, the 11th, the 20th, and the 33rd) expeditions of the Polish Academy of Sciences Henryk Arctowski Station on King George Island. During his first expedition, in 1983-1984, he wintered at the station to carry out research on the ecology of the Admiralty Bay diatoms. Professor Ligowski's pioneering studies on diatoms, a key group of primary producers in the Antarctic marine ecosystem, are a solid contribution to the knowledge on the biota of the Admiralty Bay, an area of special interest for the Polish polar studies since 1976.

Professor Ligowski was a permanent member of multi-national teams of the Biological Investigations of Marine Antarctic Systems and Stocks (BIOMASS) expeditions to the Western Antarctic in the 1980s, onboard the r/v Profesor Siedlecki. Under the auspices of the Polish Academy of Sciences, he conducted studies in the Scotia and Weddell Seas, Bransfield Strait, and off the South Shetland Islands (expeditions: BIOMASS FIBEX in 1981, BIOMASS SIBEX in 1984, the third expedition of the series in the 1986/1987 season, and the EASIZ - Ecology of Antarctic Sea Ice Zone expedition at the turn of 1989). During the austral summer 2002/2003, he carried out research as a member of the 18th Italian Antarctic expedition to the Ross Sea.

We have lost a scientist known for his absolute consistency in and unswerving passion for his scientific endeavors and plans. Faithful to the objects of his interest, he left a rich treasure trove of publications elucidating a wide array of diverse aspects of algal biology, viewed from a vast perspective of different biogeographic regions and habitats. We lost a meticulous and trustworthy man devoted to science.

We bid farewell to an involved and steadfast university teacher, a supervisor of numerous dissertations, and a mentor guiding students in their exploration of the natural world. He was a brave man, able to maintain dignity and integrity in the face of most difficult experiences of human life, responsible in carrying out his professional duties and in attending to his personal life.

We remain thankful to Professor Ligowski for the path of life we have shared, for his work with biology students, for his scientific exploration of the remote terra incognita, for scientific collaboration, and for his never-failing friendly presence.

May you rest in peace our friend, colleague, teacher and traveler! 